\title{
Ornamen Flora Teknik Kolase pada Toples Makanan Berbahan Stiker Berdasarkan Prinsip-Prinsip Seni Rupa
}

\section{Flora Ornaments Collage Techniques on Food Jars Made of Stickers Based on The Principles of Fine Art}

\author{
Rahmita Ilmi \& Azmi* \\ Pendidikan Seni Rupa, Fakultas Bahasa dan Seni, Universitas Negeri Medan, Indonesia
}

Diterima: 05 Juni 2021; Direview: 05 Juni 2021; Disetujui: 14 Agustus 2021

*email: azmits991@gmail.com

\begin{abstract}
Abstrak
Penelitian ini bertujuan untuk mengetahui kemampuan siswa dalam menerapkan ragam hias dengan teknik kolase berbahan stiker di kelas VII SMP Negeri 1 Perbaungan berdasarkan prinsip-prinsip seni rupa, yaitu kesatuan, keseimbangan dan irama. Tema yang digunakan adalah flora dengan media toples makanan. Berdasarkan hasil obervasi awal peneliti, hasil karya ragam hias siswa dengan menggunakan cat di media kertas masih kurang optimal. Serta minimnya pengetahuan siswa dalam menerapkan prinsip-prinsip seni rupa menjadi faktor pendorong hasil karya siswa menjadi kurang optimal. Adapun populasi dalam penelitian ini yaitu seluruh siswa kelas VII SMP Negeri 1 Perbaungan dengan jumlah seluruh 277 siswa dan sampelnya yaitu 21 karya siswa kelas VII-1 (unggulan) dengan menggunakan teknik Purposive Sampling. Penelitian ini menggunakan metode deskriptif kualitatif. Hasil temuan penelitian ini menunjukkan bahwa secara keseluruhan kemampuan hasil penerapan ragam hias teknik kolase kelas VII-1 berdasarkan prinsip kesatuan, keseimbangan dan irama memiliki hasil nilai rata-rata = 79,5 dengan kategori cukup baik. Secara terperinci, nilai rata-rata berdasarkan ketiga aspek sebagai berikut: kesatuan = 79,7 (cukup baik) keseimbangan = 79,5 (cukup baik) dan irama = 79,3 (cukup baik) dengan capaian indikator : kesatuan, keseimbangan, dan irama.

Kata Kunci: Ragam Hias; Kolase; Kesatuan; Keseimbangan; Irama.
\end{abstract}

\begin{abstract}
This study aims to see the ability of students to apply decorative styles with the collage technique made from stickers in class VII SMP Negeri 1 Perbaungan based on the principles of fine arts, namely unity, balance, and rhythm. The theme used is flora with food jars as media. Based on the researchers 'initial observations, the students' decorative works using paint on paper media were still not optimal. As well as the lack of student knowledge in applying the principles of fine arts is a factor driving student work to be less than optimal. The population in this study was all class VII students of SMP Negeri 1 Perbaungan with 277 students. The sample was 21 students of class VII-1 (superior) using the purposive sampling technique. This study used the descriptive qualitative method. The findings of this study indicate that, in total, the application of the ornamental variety of class VII-1 collage techniques based on the principles of unity, balance, and rhythm has an average value of $=79.5$ with a reasonably good category. In detail, the average value is based on the following three aspects: unity $=79.7$ (good enough), balance $=79.5$ (good enough), and rhythm = 79.3 (good enough) with performance indicators: unity, balance, and rhythm.
\end{abstract}

Keywords: Ornament; Collage; Unity; Balance; Rhytme.

How to Cite: Ilmi, R. \& Azmi, (2021). Ornamen Flora Teknik Kolase pada Toples Makanan Berbahan Stiker Berdasarkan Prinsip-Prinsip Seni Rupa. Journal of Education, Humaniora and Social Sciences (JEHSS). 4(2): 931-937. 


\section{PENDAHULUAN}

Pada saat ini, di Indonesia telah menerapkan kurikulum 2013 (K-13). Seni budaya adalah salah satu mata pelajaran yang ditetapkan dalam kurikulum ini. Pada umumnya kajian seni budaya terdiri dari : seni musik, seni tari, seni pertunjukan atau teater, dan seni rupa. Salah satu materi pembelajaran yang dibahas dalam seni rupa adalah ragam hias. Pada RPP SMP kelas VII/genap tahun ajaran 2019/2020, kompetensi dasar yang diharapkan pada materi pelajaran ragam hias adalah siswa dapat memahami prosedur penerapan ragam hias pada bahan tekstil dan membuat karya dengan motif ragam hias. Sedangkan indikator pencapaian untuk siswa yaitu menjelaskan prosedur penerapan ragam hias, menganalisis dan mengidentifikasi ragam hias pada bahan tekstil.

Ragam hias atau disebut sebagai ornamen merupakan materi pelajaran yang memberi wawasan pengetahuan dan kemampuan berkarya menggambar ornamen dasar dengan mengaplikasikan prinsip-prinsip seni didalamnya. Ragam hias salah satu bentuk seni rupa yang sangat melekat dengan identitas bangsa Indonesia yang tersusun dari pola-pola suatu daerah atau suku-suku yang telah membudaya (Rusdi, et al., 2020; Mustika, et al., 2020).

Pada pembelajaran seni budaya SMP N 1 Perbaungan, penerapan materi ragam hias di media bidang datar seperti kertas dengan menggambar dan mewarnainya dengan macam-macam jenis cat merupakan bentuk penugasan dari waktu ke waktu sudah menjadi tugas yang rutin dikerjakan pada mata pelajaran ragam hias tersebut. Para siswa yang sebelumnya sudah mempelajari materi pelajaran ragam hias, ditemukan beberapa masalah. Hasil karya ragam hias mereka belum memenuhi indikator prinsip-prinsip seni. Seperti kesatuan, keseimbangan, proporsi, dan irama.

Terbatasnya literatur atau buku bacaan tentang materi pelajaran ragam hias membuat siswa kurang mengeksplore pengetahuan tentang ragam hias. Sehingga hasil karya siswa tidak sesuai dengan prinsip seni. Lalu siswa kelas VII-1 sebelumnya mengalami kesulitan dalam menggambar/merancang dan mengecat pola ragam hias pada media kertas.

Karena menerapkan ragam hias di media kertas dianggap kurang efektif untuk siswa sebelumnya, maka alternatif untuk siswa yang saat ini akan mempelajari mata pelajaran ragam hias, Guru seni budaya akan menerapkan suatu teknik baru pada siswa kelas VII SMP Negeri 1 Perbaungan. Teknik dalam seni rupa yang dianggap mampu membantu mengatasi masalah dalam penelitian ini yaitu teknik kolase. Teknik kolase merupakan teknik melukis dengan menempel bahan-bahan seperti kertas, serpihan kayu,biji-bijian dan lain-lain pada pola yang sudah ditentukan di suatu media.

Penerapan. Menurut Kamus Besar Bahasa Indonesia (KBBI, 2003) penerapan adalah perbuatan menerapkan. Menurut Suardi (1986) penerapan adalah konkrit situasional dan terikat pada ruang dan waktu. Dengan demikian ada keterbatasan dan pembatasan, karena manusia selalu terikat dengan alam sekitarnya. Jadi kebebasan harus dilakukan dengan mengingat kepentingan dan ketertiban umum. Pengertian Teknik. Menurut Sukiman (2012), "Teknik adalah cara seseorang mewujudkan gagasan (ide) menjadi sesuatu yang menarik sehingga mempunyai nilai perwujudan dengan penggunaan media yang berupa alat dan bahan seni rupa". Teknik berkarya adalah teknik yang digunakan dalam memberi bentuk atau wujud yang berbeda. Dalam Kamus Besar Bahasa Indonesia (2005) "Teknik adalah pengetahuan dan kepandaian membuat sesuatu yang berkenaan dengan hasil industri".

Ragam Hias (Ornamen). Menurut Sirait (1980) dalam bukunya laporan penelitian pengumpulan dan dokumentasi ornamen tradisional di Sumatera Utara menyebutkan bahwa: "Istilah ragam hias berasal dari dua perkataan ragam dan hias yang terpadu menjadi satu pengertian pola. Dalam bahasa Inggris disebut ornament dan dalam bahasa Belanda dikatakan siermotieven. Ornamen adalah cabang seni rupa yang di dalamnya banyak ditemukan nilai-nilai simbolik atau maksud-maksud tertentu yang ada hubungannya dengan pandangan hidup atau filsafat hidup dari manusia atau masyarakat penciptanya. Dalam wujudnya ornamen dapat berupa bentuk dua dimensional maupun tiga dimensional sesuai dengan corak dan gaya masing-masing etnis (Atmojo et al, 2018; Utami, et al., 2020; Saulaka, et al., 2020). Fungsi Ragam Hias. Ragam hias atau ornamen dimaksudkan untuk menghias suatu bidang atau benda, sehingga benda 
tersebut menjadi indah (Sila et al, 2013). Jenis Motif Ragam Hias: Geometris; Fauna / Hewan; Flora / Tumbuhan

Pengertian Kolase. Kolase berasal dari bahasa perancis collage yang berarti merekat. Kolase adalah kreasi aplikasi yang dibuat dengan menggabungkan tekhnik melukis (lukisan tangan) dengan menempelkan bahan-bahan tertentu (Sumanto, 2005). Kolase merupakan teknik dalam berkarya seni dengan cara menempel bahan pada bidang datar (Samsiatul Makrifa,2014). Kolase ialah suatu karya yang menggunakan bermacam-macam bahan seperti potongan-potongan, batuanbatuan, kaca berwarna, porselin, dan bahan dasar lainnya yang mampu dipadukan satu sama lain (Susiani et al, 2018). Bahan. Bahan adalah zat atau benda yang dibutuhkan untuk membuat sesuatu.pengertian secara umum bahan adalah material dasar yang bisa berasal dari berbagai tempat yang mana bahan tersebut dapat digunakan untuk diolah dengan suatu proses tertentu ke dalam tempat lain.

Prinsip Seni Rupa. Prinsip seni rupa merupakan landasan dalam membuat karya seni, dalam suatu karya seni yang dapat dinikmati dari segi estetik dan sedap dipandang mata merupakan karya seni yang menerapkan prinsip-prinsip seni rupa (Utoyo, 2020). Prinsip-prinsip seni rupa adalah cara penyusuan, pengaturan unsur-unsur rupa sehingga membentuk suatu karya seni. Prinsip Seni Rupa dapat juga disebut asas seni rupa, yang menekankan prinsip desain seperti: kesatuan, keseimbangan, irama, penekanan, proporsi dan keselarasan. Prinsip kesatuan sesungguhnya ialah adanya saling hubungan antarunsur yang disusun (Sanyoto, 2009). Dijelaskan bahwa ada tujuh prinsip-prinsip dasar seni rupa dan desain, meliputi antara lain keselarasan/irama/ritme, kesatuan (unity), dominasi/daya tarik/pusat perhatian, keseimbangan, keserasian/proporsi/perbandingan, kesederhanaan, dan kejelasan (Agustin et al, 2020). Keseimbangan adalah hubungan antara kekuatan-kekuatan yang bertentangan. Secara umum dikenal dua tipe keseimbangan yaitu : simetris dan a simetris (Sembiring, 2014). Irama ditimbulkan dari kesan gerak dan unsur yang melekat pada karya seni. Sifat atau kesan dari irama dapat lemah lembut keras atau lunak secara teratur (Mesra, 2013). Dari pembahasan awal disimpulkan bahwa penelitian ini ingin menerapkan teknik kolase untuk memberikan alternatif baru pada siswa SMP Negeri 1 Perbaungan kelas VII di dalam mata pelajaran seni budaya materi ragam hias. Sehingga dengan adanya eksperimen ini, semakin banyak ide kreatif baru.

\section{METODE PENELITIAN}

Subjek penelitian ini diterapkan pada siswa kelas VII SMP Negeri 1 Perbaungan yang beralamat di Jalan Medan-Tebing Tinggi Km. 40 Kelurahan Tualang, Kecamatan Perbangunan, Kabupaten Serdang Bedagai, Provinsi Sumatera Utara. Jenis penelitian ini adalah penelitian deskriptif kualitatif, yaitu data yang dikumpulkan berbentuk kata-kata, gambar, bukan angkaangka. Teknik pengambilan data dengan cara observasi dan dokumentasi.

Dalam penelitian ini, peneliti menggunakan purposive sampling. Purposive sampling menurut Sugiyono adalah teknik penentuan sampel dengan pertimbangan tertentu (Sugiyono, 2012). Maka dalam penelitian ini yang menjadi sampel penelitian adalah siswa kelas VII - 1 (Unggulan) SMP Negeri 1 Kecamatan Perbaungan yang berjumlah 25 orang. Karena diharapkan kelas VII-1 lebih mampu dalam menerima dan lebih kompeten dalam penerapan teknik baru di penelitian ini. Dalam penelitian ini, peneliti menerapkan ragam hias flora teknik kolase pada toples makanan dengan bahan stiker karya siswa kelas VII SMP Negeri 1 Perbaungan ditinjau dari prinsip-prinsip seni rupa. Karya yang diteliti berjumlah 21 karya siswa kelas VII-1 . Karya akan dinilai oleh peneliti berdasarkan indikator dan deskriptor unsur-unsur seni rupa yang sudah ditetapkan oleh peneliti.

Hasil penelitian tersebut dinilai dalam bentuk tabulasi data berupa instrumen penilaian lalu dianalisis dan dideskripsikan oleh peneliti. Kemudian hasil penelitian dalam bentuk tabulasi tersebut digabungkan dengan jumlah rata-rata tiap prinsip seni rupa, yaitu kesatuan, keseimbangan dan irama.

Dalam penelitian ini, peneliti menganalisis data menggunakan penilaian, seperti berikut:

a. $90-100$ (Sangat Baik) 
Rahmita Ilmi \& Azmi, Ornamen Flora Teknik Kolase pada Toples Makanan Berbahan Stiker Berdasarkan PrinsipPrinsip Seni Rupa
b. $80-89$ (Baik)
c. $70-79$ (Cukup Baik)
d. $<70$ (Kurang Baik)

Tabel. 1. Format Penilaian Siswa

\begin{tabular}{lllll}
\hline & & Aspek yang dinilai & Jumlah & Rata-rata \\
\cline { 3 - 4 } No. Nama Siswa & Kesatuan & Keseimbangan & Irama & \\
\hline $\mathbf{1}$ & & & \\
\hline 3 & & & \\
\hline$\ldots$ & & & \\
\hline dst & & & \\
\hline
\end{tabular}

\section{HASIL DAN PEMBAHASAN}

Hasil Penilaian Karya Siswa

Hasil Penerapan Ragam Hias Flora Teknik Kolase Pada Toples Makanan Dengan Bahan Stiker Karya Siswa Kelas VII SMP Negeri 1 Perbaungan Ditinjau Dari Prinsip-Prinsip Seni Rupa, maka diperoleh data-data sebagai berikut :

\section{Karya Ajibsyah Pratama}

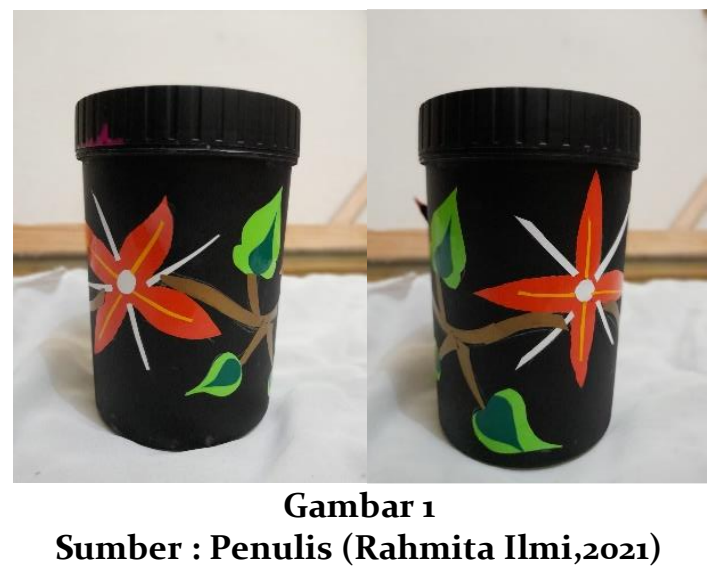

Hasil karya Ajibsyah Pratama merupakan motif daun dan bunga. Ditinjau dari prinsip kesatuan, motif bunga dan tangkai sudah menimbulkan kesan yang bersatu, hanya saja penataan letak motif daun yang membuat kesatuannya kurang baik. Dari segi keseimbangan sudah cukup baik, bobot motif bunga seimbang, tetapi letak motif daun hijau yang berada ditengah membuat kesan berat sebelah atau timpang. Dari segi irama pengulangan pola dan motif sudah cukup baik, hanya saja bentuk motif tidak bervariasi.

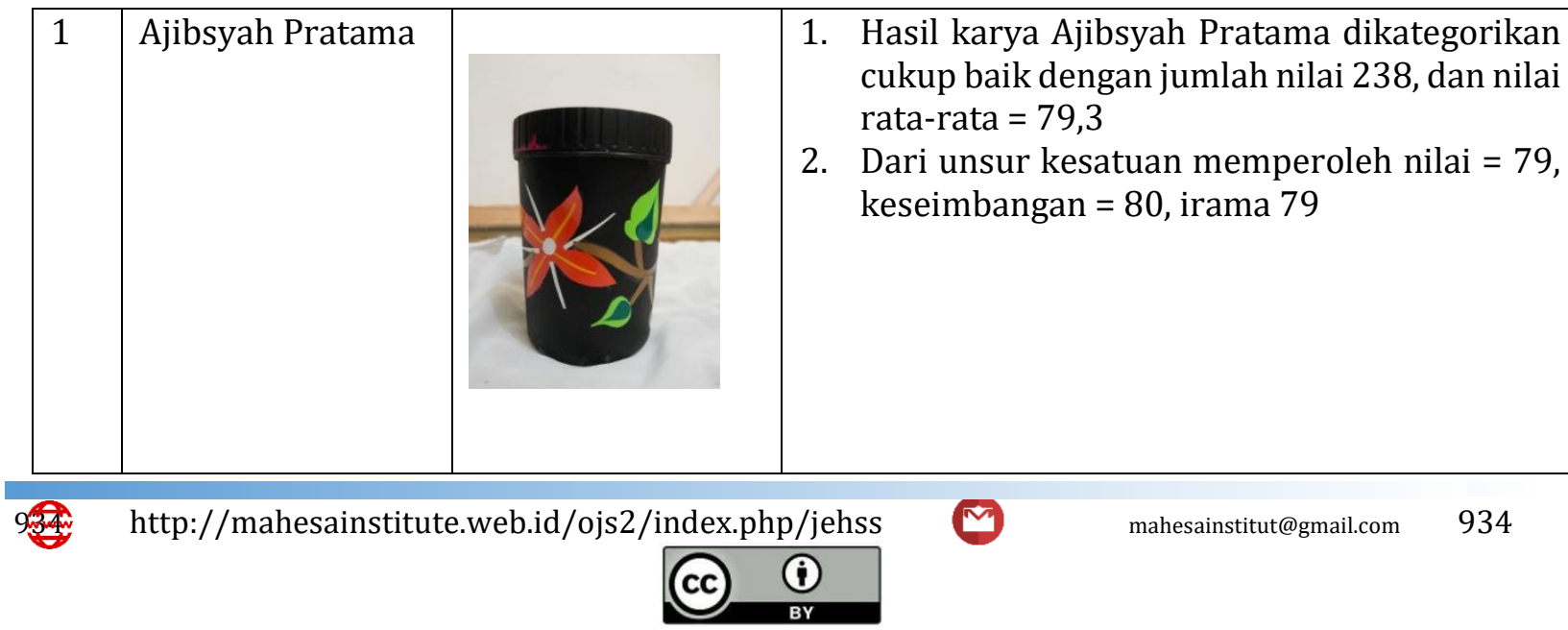




\section{Karya Ali Akbar}

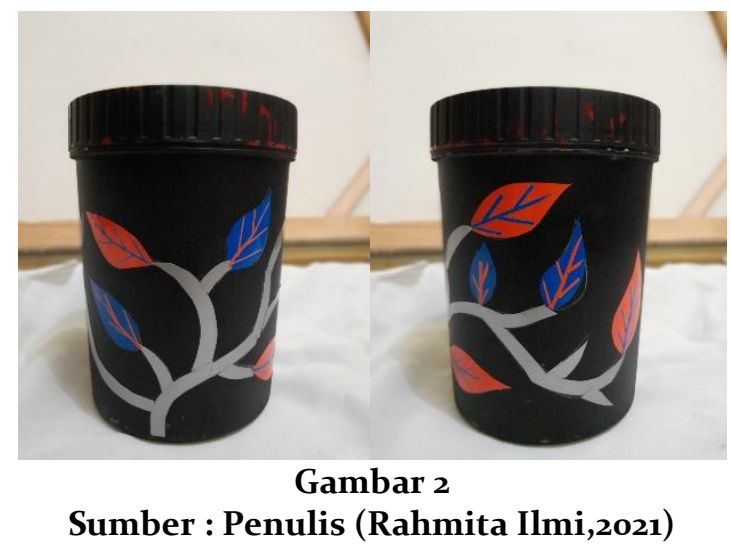

Hasil karya Ali Akbar mempunyai motif daun dan tangkai yang cukup rapi, bentuk daun dan batang daun di gunting secara rapi. Ditinjau dari prinsip kesatuan, motif daun dan tangkai nya mempunyai kesan bersatu yang bagus. Motif dan pola yang dibuat terorganisir dengan baik. Dari segi keseimbangan, bobot motif dan pola yang dibuat bagus tidak berat sebelah. Dari segi irama, penataan pengulangan motifnya bagus, ukuran motif daun juga bervariasi sehingga terjadi pengulangan ukuran dan menimbulkan kesan gerak.

\begin{tabular}{|l|l|l|}
\hline 2 & Ali Akbar & $\begin{array}{l}\text { 1. } \begin{array}{l}\text { Hasil karya Ali Akbar dikategorikan cukup } \\
\text { baik dengan jumlah nilai 251, dan nilai rata- } \\
\text { rata }=83,6\end{array} \\
\text { Dari unsur kesatuan memperoleh nilai }=84, \\
\text { keseimbangan = 82, irama 85 }\end{array}$ \\
\hline
\end{tabular}

\section{Karya Allfin Bomantra}

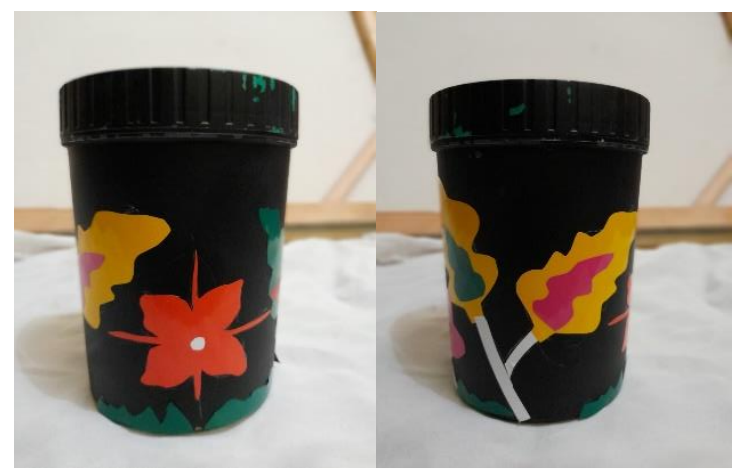

Gambar 3

Sumber : Penulis (Rahmita Ilmi,2021)

Hasil karya Allfin Bomantra merupakan motif dedaunan, rumput dan bunga. Ditinjau dari prinsip kesatuan cukup baik, hanya saja terdapat motif yang terkesan tidak ada kaitannya dengan motif lainnya, yaitu motif bunga bewarna orange dan 2 bunga kecil yang ada di sisi sebaliknya yang terletak di bawah. Dari segi keseimbangan terdapat motif yang berbeda antar motif lainnya

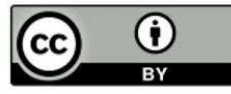


Rahmita Ilmi \& Azmi, Ornamen Flora Teknik Kolase pada Toples Makanan Berbahan Stiker Berdasarkan Prinsip-

Prinsip Seni Rupa

sehingga menimbulkan kesan tidak seimbang. Terdapat jarak yang sangat rapat antar motif daun kuning yang besar dengan daun merah muda yang besar. Dari segi irama, pengulangan pola kurang teratur.

\begin{tabular}{|l|l|l|l|}
\hline 3 & Allfin Bomantra & $\begin{array}{l}\text { 1. } \\
\text { Hasil karya Allfin Bomantra dikategorikan } \\
\text { cukup baik dengan jumlah nilai 234, dan } \\
\text { nilai rata-rata =78 } \\
\text { Dari unsur kesatuan memperoleh nilai =78, } \\
\text { keseimbangan = 78, irama 78 }\end{array}$ \\
\hline
\end{tabular}

\section{Karya Amita Minarti}

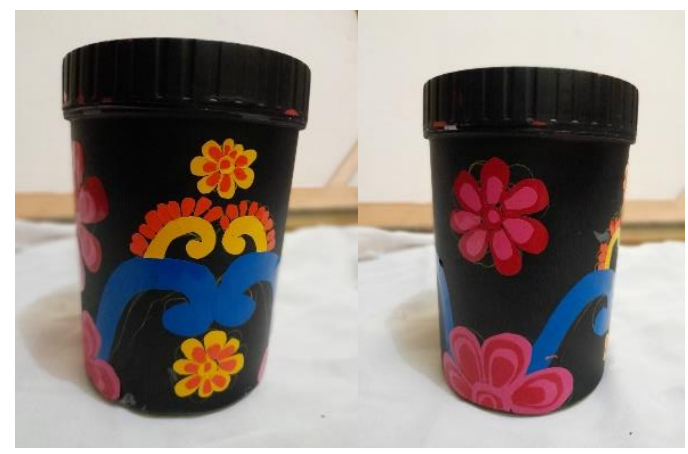

Gambar 4

Sumber : Penulis (Rahmita Ilmi,2021)

Hasil karya Amita Minarti merupakan motif bunga-bunga. Hasil guntingan pola dan tempelan pola rapih dan rinci. Ditinjau dari prinsip kesatuan terdapat perpaduan antar motif yang tertata dengan baik sehingga menimbulkan adanya hubungan keterkaitan antar motif. Dari segi keseimbangan, jarak antar dan bobot motif tertata dengan baik, hanya saja motif bunga merah muda yang ada di bagian atas dan di tengah-tengah bunga kuning berbeda. Bunga yang satu bobotnya lebih besar, sedangkan yang lainnya lebih kecil. Dari segi irama terdapat pengulangan motif dan pola yang baik tertata secara baik sehingga menimbulkan kesan gerak.

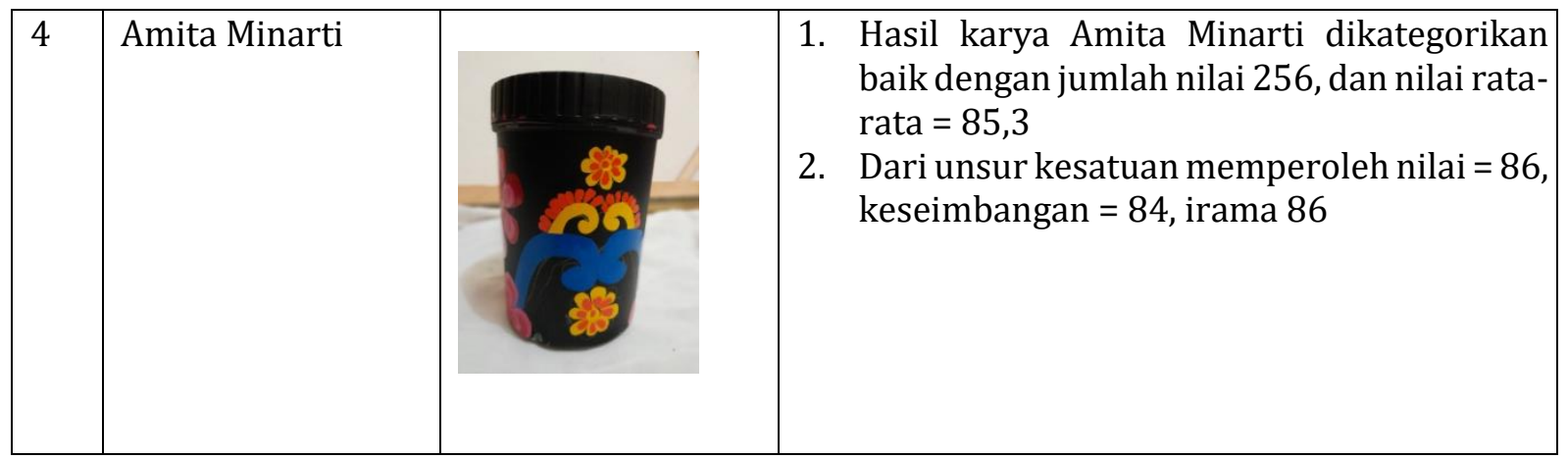

Tabel 2. Penilaian Akhir Siswa

\begin{tabular}{llllllll}
\hline NO & Nama Siswa & Kesatuan & Keseimbangan & Irama & Jumlah & Rata-Rata & Ket \\
\hline 1 & Ajibsyah pratama & 79 & 80 & 79 & 238 & 79,3 & C \\
\hline 2 & Ali Akbar & 84 & 82 & 85 & 251 & 83,6 & B \\
\hline 3 & Allfin Bomantra & 78 & 78 & 78 & 234 & 78 & C \\
9360 & http://mahesainstitute.web.id/ojs2/index.php/jehss & $\sqrt{3}$ & & mahesainstitut@gmail.com & 936
\end{tabular}


Vol 4, No. 2, November 2021: 931-937

\begin{tabular}{lllllll}
$4 \quad$ Amita Minarti & 86 & 84 & 86 & 256 & 85,3 & B \\
\hline Jumlah & 327 & 324 & 328 & 979 & 326,2 \\
\hline Rata-Rata & 81,75 & 81 & 82 & 244,7 & 81,55 \\
\hline Keterangan & B & B & B & B & B \\
\hline
\end{tabular}

\section{SIMPULAN}

Pada prinsip kesatuan siswa sudah mampu meletakkan pola dan motif yang tertata dan terorganisir dengan cukup baik sehingga mampu menunjukkan adanya hubungan keterkaitan antar bentuk motif dan pola. Meskipun ada beberapa yang masih belum sesuai dengan penerapan prinsip kesatuan tersebut dengan nilai rata-rata $=81,75$ (Baik). Pada prinsip keseimbangan siswa sudah mampu menata pola dan bentuk motif dengan memperhatikan bobot ukuran, posisi dan pengulangan motif nya dengan cukup baik dengan nilai rata-rata $=81$ (Baik). Pada prinsip irama siswa sudah mampu menata pengulangan motif dan pola dengan cukup baik. Mampu membuat bentuk dan ukuran motif yang berbeda-beda sehingga tercipta kesan gerak yang cukup baik dengan rata-rata = 82 (Baik). Dan nilai rata-rata mendapat 81,55 (Baik)

\section{DAFTAR PUSTAKA}

Agustin, T., \& Ibrahim, A. (2020). Analisis Kaligrafi Kontemporer Dari Aspek Keterbacaan Huruf Dan Warna. Journal of Education, Humaniora and Social Sciences (JEHSS), 3(1), 187-192.

Atmojo, W.T., \& Misgiya. (2018). Eksplorasi Dan Implementasi Ornamen Sumatera Utara Dalam Karya Batik. Jurnal artchive. 1 (1).

Makrifa, S. (2014). Pemanfaatan Daun Kering Sebagai Media Berkarya Kolase pada Kegiatan Ekstrakulikuler Seni Rupa di Sd Sekaran 01 Gunung Pati Semarang. Journal of Visual Arts, 3(1), 11.

Mesra. (2013). Menggambar Bentuk 1. Medan : Unimed Press.

Mustika, A., \& Erdansyah, F. (2020). Analisis Ornamen (Gerga) Tradisional Karo pada Bangunan Kantor Bupati Karo Kabupaten Karo. Journal of Education, Humaniora and Social Sciences (JEHSS), 3(1), 16170. doi:https://doi.org/10.34007/jehss.v3i1.243

Rusdi, L., Soeprayogi, H., \& Mesra, M. (2020). Kerajinan Anyaman Bambu Di Sanggar Kreatif "Bunga Matahari" Kelurahan Rambung Barat Kecamatan Binjai Selatan. Journal of Education, Humaniora and Social Sciences (JEHSS), 3(1), 133-140. doi:https://doi.org/10.34007/jehss.v3i1.216

Sanyoto, S.E. (2009). Nirmana : Elemen-elemen Seni dan Desain. Yogyakarta. Jalasutra.

Saulaka, O., Mesra, M., \& Daulat, D. (2020). Analisis Kerajinan Boneka Berbahan Koran Bekas Produk Galeri J-ART. Journal of Education, Humaniora and Social Sciences (JEHSS), 3(2), 294-300. doi:https://doi.org/10.34007/jehss.v3i2.205

Sembiring, D. (2014). Wawasan Seni. Medan : Unimed Press.

Sila, N., \& Ayu. (2013). Kajian Estetika Ragam Hias Tenun Songket Jinengdalem, Buleleng. Jurnal Ilmu Sosial dan Humaniora. 2(1), 158.

Sirait, B. (1980). Pengumpulan dan Dokumentasi Ornamen Tradisional di Sumatera Utara. IKIP.

Sugiyono. (2017). Metode Penelitian Pendidikan. Bandung: Alfabeta

Sumanto. (2005). Pengembangan Kreativitas Seni Rupa Anak TK. Jakarta. Depdiknas.

Susiani, T., Priyatnomo, M., \& Tantifah, L. (2018). Implementation of Collage Skills on Early Childhood Creativity. SHEs : Conference Series. 1(2), 476.

Utami, A., Soeprayogi, H., \& Azis, A. (2020). Pembuatan Kerajinan Bunga Berbahan Kulit Jagung Ditinjau dari Prinsip-prinsip Seni Rupa dan Kerajinan. Journal of Education, Humaniora and Social Sciences (JEHSS), 3(1), 260-264. doi:https://doi.org/10.34007/jehss.v3i1.282

Utoyo, T., Priyatno, A., \& Azis, A. (2020). Penerapan Prinsip-prinsip Seni Rupa pada Kaligrafi di Masjid Baiturrahman Unimed. Journal of Education, Humaniora and Social Sciences (JEHSS). 3(2), 420.

http://jurnal.untan.ac.id/index.php/jpdpb/article/download/16385/14226 12 Desember 2019/21:15:03

https://agroedupolitan.blogspot.com/2017/02/pengertian-kolase.html 12 Desember 2019/21:24:17

https://man1jepara.sch.id/pengertian-fungsi-dan-motif-ornament/ 13 Desember/00:15:04

https://serupa.id/ragam-hias-pengertian-motif-teknik/\#.Xc63y9UzbIU 13 Desember/00:30:10 